\title{
透析症例および SLEにおける凝固・線溶の
}

$$
\text { 分子マーカーの変動 }
$$

\begin{tabular}{|c|c|c|c|}
\hline 彦* & 隆* & 良一* & 丹羽 \\
\hline 俊彦* & 川辰雄* & 山本 雅敏* & 弘親* \\
\hline 譲* & 椙江 & 々 田健四郎*** & 小林 柾樹* \\
\hline
\end{tabular}

Plasma values of coagulation and fibrinolytic molecular markers in dialysis and SLE

\author{
Tomohiko AOYAMA*, Takashi OGURI*, Ryoichi KATO*, \\ Tadashi NIWA*, Toshihiko BANNO*, Tatsuo HASEGAWA* \\ Masatoshi YAMAMOTO*, Hirochika MENJO*, Yuzuru SUGAWARA*, \\ Isamu SUGIE**, Kenshirou SASADA*** and Masaki KOBAYASHI****
}

Key words: FPA, B $\beta$ 1-42, B $\beta$ 15-42, t-PA, Dialysis

For the analysis of thrombophilic state in patients of dialysis, SLE and diabetes mellitus (DM), we examined the molecular markers of coagulation and fibrinolytic system in plasma, i.e. Fibrinopeptide A (FPA), fibrinopeptide $\mathrm{B} \beta 1-42,15-42$, (B $\beta 1-42,15-42)$, tissue type plasminogen activator (t-PA). The mean values of normal adults $(n=20)$ were as follows; FPA $1.69 \pm 0.23 \mathrm{ng} / \mathrm{ml}, \mathrm{B} \beta 1-423.12 \pm 0.48 \mathrm{pmole} / \mathrm{ml}, \mathrm{B} \beta 15-423.41 \pm 0.53 \mathrm{pmole} /$ $\mathrm{ml}$, t-PA $8.25 \pm 2.34 \mathrm{ng} / \mathrm{ml}$. In the patients on dialysis $(\mathrm{n}=30)$, a tendency of increase in the plasma concentrations of FPA and B $\beta 1-42$ was showed, but the low levels of the plasma concentrations of t-PA were observed. The levels of $\mathrm{B} \beta 15-42$ in plasma were almost normal. According to the clinical course of dialysis, we divided the patients into two groups, less and more than 5 years. In the former group, the mean plasma concentration of $\mathrm{B} \beta 1-42$ was $35.57 \pm 23.67 \mathrm{pmole} / \mathrm{ml}, \quad \mathrm{B} \beta 15-42$ was $5.44 \pm 1.29 \mathrm{pmole} / \mathrm{ml}$.

* 愛知医科大学第二内科 [₹ $480-11$ 愛知県愛知郡長久手町 $]$, Second Department of Internal Medicine, Aichi Medical Univesity, Aichi. Japan.

** 同 第一生理, First Department of Physiology, Aichi Medical University, Aichi, Japan.

*** 同 皮虙科, Department of Dermatology, Aichi Medical Univesity, Aichi, Japan.

***** 生命情報分析センター, Life Information analysis Center. Aichi, Japan. 
In the latter group, the plasma concentration of $\mathrm{B} \beta 1-42$ was $29.56 \pm 27.24$ $\mathrm{pmole} / \mathrm{ml}, \mathrm{B} \beta 15-42$ was $6.47 \pm 1.26 \mathrm{pmole} / \mathrm{ml}$. On the contrary, in the caces of SLE patients less than 5 years $(n=10)$ and DM patients more than 10 years $(n=10)$, the concentrations of $B \beta 1-42$ was within normal value, but $\mathrm{B} \beta 15-42$ was apparently increased. As a result of these examinations, it was suggested that these patients were in hypercoagulable state, but the fibrin formations could not be complete in the cases of dialysis patients.

$$
\text { はじめに }
$$

凝固・線溶因子のモノクローナル抗体の普及 により, 血栓性素因の検索として凝固・線溶因 子の中間産物である分子マーカー1 3) が検討さ れている，今回われわれは腎透析症例，SLE 括 よび糖尿病症例に抢ける血漿中 Fibrinopeptide A(FPA), Fibrinopeptide B $\beta$ 1-42 (B $\beta$ 1-42) $)^{4}$, 同 $\mathrm{B} \beta$ 15-42 $\left(\mathrm{B} \beta\right.$ 15-42) ${ }^{5)}$, Tissue type plasminogen activator $(\mathrm{t}-\mathrm{PA})^{6,7)}$ について検討し た.

\section{I. 万 法}

腎透析症例 30 例を透析経過年数 5 年前後で分 類し, 凝固・線溶因子の分子マーカーを検討し た. また対照として経過 5 年以下の SLE 症例 (10例), 羅患 10 年以上の糖尿病症例 10 例も同様 に検討した，検体採取は，19G 針を用い無駆血 または短時間駆血で 2 シリンジ法により行な い，即時にヘパリン $500 \mathrm{IU} ，$ アプロチニン 500 IU 混合溶液 1 容に対し血液 9 容を混和したも のを Fibrinopeptide 用検体とし，同様に $3.8 \%$ クエン酸ソーダに混和したものを $\mathrm{t}-\mathrm{PA}$ 用検体 とした. $3000 \mathrm{Gx} 15$ 分間遠心分離後の上澄を

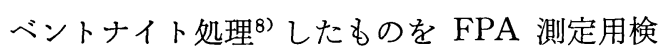
体, 同上澄を Centricon ${ }^{\mathrm{TM}} 30$ microconcentrator により膜透過処理したものを $\mathrm{B} \beta$ peptide 測定 用検体, 上澄を酸処理し $\mathrm{pH}$ を再調整したもの を t-PA 測定用検体とした. FPA は EIA 法 (Stago 社 FPA kit), B $\beta$ 1-42 B $\beta$ 15-42 は E IA 法 (New York Blood Center B $\beta$ Peptide Assays), t-PA は EIA 法 (Biopool 社 t-PA kit）を用い測定した.

\section{II. 結果および考察}

フィブリノーゲンおよびフィブリンの各種分 解産物 ${ }^{9)}$ と $\mathrm{B} \beta$ peptide に対する Monoclonal Antibody との反応では， B $\beta$ 1-42 に対する抗

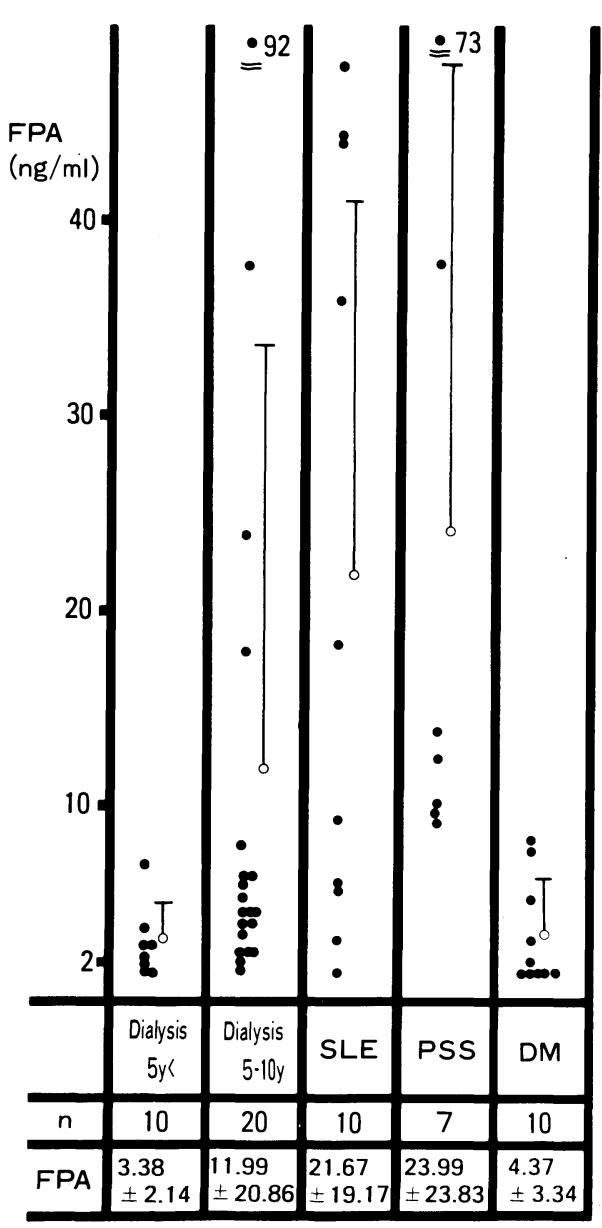

Fig. 1 Plasma FPA levels in dialysis SLE and DM 

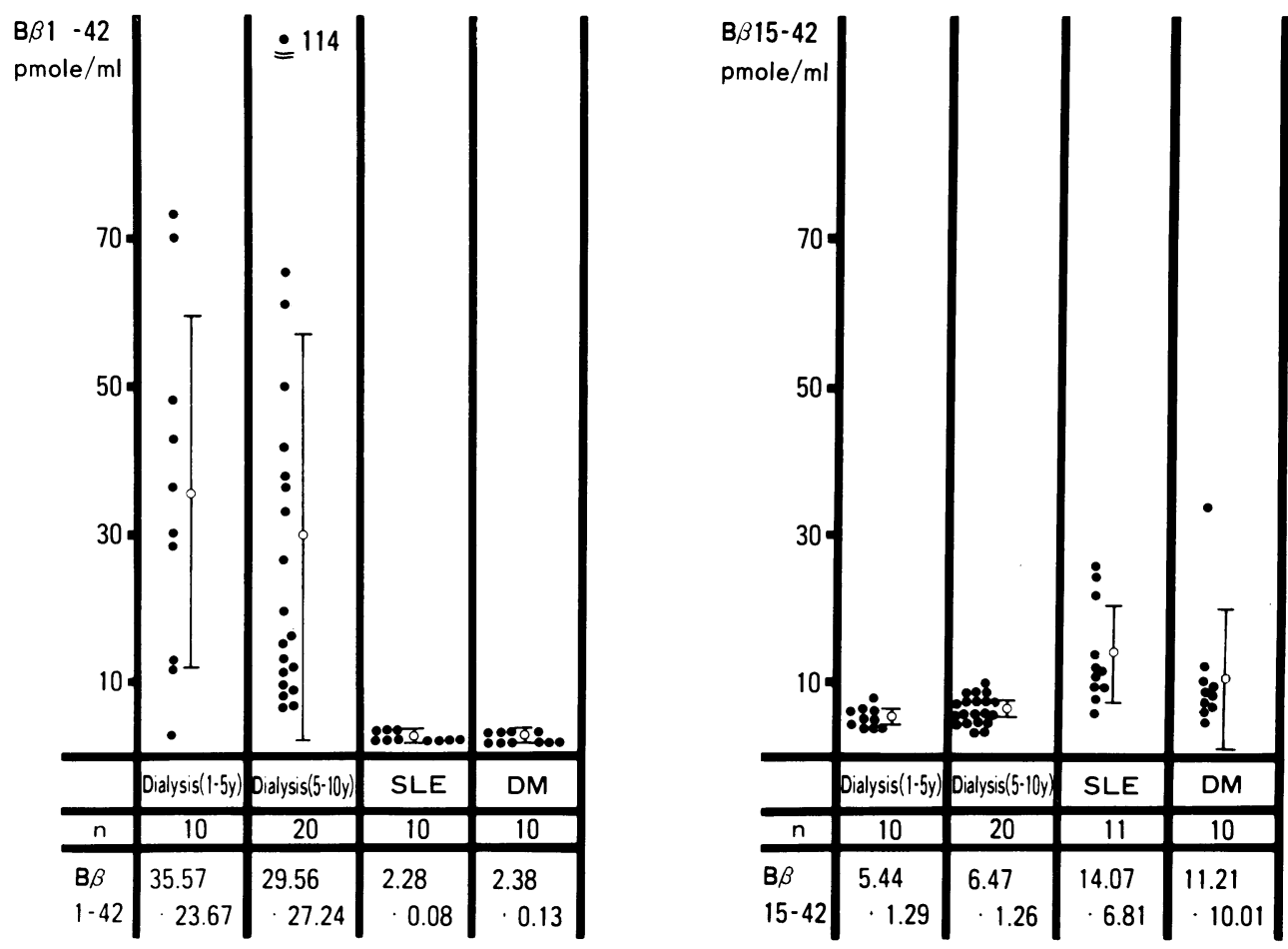

Fig. 2 Plasma B $\beta$ peptide levels in dialysis SLE and DM

体はフィブリノーゲンと，B $\beta$ 15-42 に対する 抗体は D-dimer と交叉反応を認めた。 健常者 $(\mathrm{n}=20)$ に扣ける平均值は, FPA $1.69 \pm 0.23$ $\mathrm{ng} / \mathrm{m} l, B \beta 1-423.12 \pm 0.48 \mathrm{pmole} / \mathrm{m} l, \mathrm{~B} \beta$ $15-423.41 \pm 0.53 \mathrm{pmole} / \mathrm{ml}, \mathrm{t}-\mathrm{PA} 8.25 \pm 2.34$ $\mathrm{ng} / \mathrm{m} l$ であった. 疾患群に执いて経過 5 年以下 の腎透析症例では FPA $3.38 \mathrm{ng} / \mathrm{m} l, \mathrm{~B} \beta$ 1-42 $35.57 \pm 23.67 \mathrm{pmole} / \mathrm{m} l, \mathrm{~B} \beta 15-425.44 \pm 1.29$ pmole $/ \mathrm{ml}$, t-PA $3.7 \pm 5.5 \mathrm{ng} / \mathrm{ml}$ であり, 同 5 年以上例では FPA $11.99 \pm 20.86 \mathrm{ng} / \mathrm{ml}$,

$\mathrm{B} \beta$ 1-42 29. $56 \pm 27.24 \mathrm{pmole} / \mathrm{m} l, \quad \mathrm{~B} \beta$ 15-42 $6.47 \pm 1.26$ pmole $/ \mathrm{m} l, \quad \mathrm{t}-\mathrm{PA} 3.4 \pm 1.0 \mathrm{ng} / \mathrm{m} l$ であった, 一方 SLE 症例では FPA $21.67 \pm$ $19.17 \mathrm{ng} / \mathrm{m} l, \mathrm{~B} \beta 1-422.28 \pm 0.08$ pmole $/ \mathrm{m} l$, B $\beta$ 15-42 $14.07 \pm 6.81 \mathrm{pmole} / \mathrm{ml}, \quad \mathrm{t}-\mathrm{PA} 13.0$ $\pm 2.9 \mathrm{ng} / \mathrm{m} l$ と, 腎透析症例に比し対照的な結 果が得られた。 また糖尿病患者に打いてもSLE 症例と同様の傾向が見られた. 以上の事より今 回測定対象とした各種疾患群はいずれも凝固立 進状態にあることが示唆された。

腎透析症例では FPA，B $\beta$ 1-42 值の上昇に
比し B $\beta$ 15-42 值が低值であった。これは腎障 害の程度, 透析による影響 (無尿・クリアラン ス等) ${ }^{10 \sim 11) ~ あ あ る か ， ~ F i b r i n o g e n ~ よ り の ~ F P A ~}$ 放出による Fibrin I $^{9)}$ が形成されているもの の, さらに FPB を放出した後の Fibrin II ${ }^{9}$ 形 成に至る例が少ないことによるものと思われ た. SLE，糖尿病症例では，Fibrin II 形成拉よ び Fibrinolysis の京進状態にある事が示唆され た. また t-PA 值は 5 年以内の活動期の SLE では高值であり, 腎透析症例では低值を示した が， t-PA 活性扣よび腎透析に伴う諸種の因子 の検討も含め今後の課題としたい.

\section{文献}

1) Gaffneyp, J., Mahmoud, F.J., Fossati, C.A., Spitz, M.: A novel radio immunometric approach to the assay of components of human haemostasis: Assay of plasma fibrinopeptide A levels. Thromb. Res., 19; 815 822, 1980.

2) Soria, J., Soria, C., Rickwaert, J.J.: 
A solid phase immuno enzymological assay for the measurement of human fibrinopeptide A. Thromb. Res., 20; 425 435, 1980.

3) Nossel, H.L.: Relative proteolysis of the fibrinogen B-beta chain by thrombin and plasmin as a determinant of thrombosis. Nature, 291; 165 167, 1981.

4) Kudryk, B., et al.: A monoclonal antibody with the ability to distinguish between fragments derived from fibrinogen and fibrin. Mol. Immunol., 20; 1191 1200, 1983.

5) Kudryk, B., et al.: Specifity of a monoclonal antibody for the $\mathrm{NH}_{2}$-terminal region of fibrin. Mol. Immunol., 21; $89 \sim 94,1984$.

6) Bergsdorf, N., Nilsson, T., Wallen, P.: An enzyme linked immunosorbent assay for determination of tissue plasminogen activator applied to patients with thromboembolic disease. Thromb. Haemost., 50; 740 744, 1983.

7) Rijken, D.O., Juhan-Vague, I., De Cock, F., Collen, D.: Measurement of human tissue-type plasminogen activator by a two-site immunoradiometric assay. J. Lab. Clin. Med., 101; 274 284, 1983.

8) Carolina, K., Siw, F.: Rapid radioimmuno assay of human fibrinopeptide A-removal of cross-reacting fibrinogen with bentonite. Thromb. Res., 19; 589 598, 1980.

9) Bromba, B. CH, et al.: A two-step fibrinogen-fibrin transition in blood coagulation. Nature, 275; 501 505, 1978.

10）戸村 成男, 桜井一郎, 栗山廉二朗 : 糸球体腎 炎，ネフローゼ症候群に拈ける血漿 fibrino peptide $A, B \beta 15-42$ 拉よび bradikinin. 血液と 脈管, 15；371 374, 1978.

11）巽 陽一，巽 純子，巽 典之：腎不全の血中 FPA 执よび B $\beta$ 15-42 について，血液と脈管， $15 ; 687 \sim 689,1984$.

\section{・葉酸研究の完全なる集大成！ 菜酸一基礎と臨床}

編集 京都大学内科教授 内野治人 岐阜歯科大学内科教授 外林秀紀 専門医18氏分担執筆 A 5 判 484頁 図172 表104 定価9,800円(干300円) 